\title{
埋立材として用いる水砕スラグの環境影響予測 一大型水路実験および海水の化学平衡と土の緩衝特性を考慮した移流拡散解析一
}

\author{
藤原隆一* ・馬場慎太郎 $* *$ 小 小竹康夫* \\ 守谷壮之***. 中谷 行男 $* * * *$
}

\begin{abstract}
水砕スラグは土木材料としての有用性が高いが，水と接するとアルカリ分が溶出し $\mathrm{pH}$ が高くなる. 埋立材として利用す る場合, 水砕スラグからの高 $\mathrm{pH}$ の溶出水は地盤内を通って海域に出るが, その間に海水の化学反応や地盤の緩衝効果など の影響を受け, $\mathrm{pH}$ は低下寸る. 本研究では, 実験水路内に現地材料を用いて $1 / 5$ の断面を再現し, 海水の給排水による潮 汐変動を与えたときの $\mathrm{pH}$ の時間・空間変化を定量的に明らかにすることで，現地での $\mathrm{pH}$ の影響を推察した．また移流拡 散解析を行い, 大型水路実験の再現を試みた．その結果, 海水の化学平衡と土の緩衝効果を考慮することで, 実験時の $\mathrm{pH}$ の時間・空間変化をよく表すことを確認した.
\end{abstract}

\section{1.はじめに}

水砕スラグは，高炬から取り出されたスラグを急激に 冷却することでガラス質の粒状としたもので製鉄時の副 産物として精製される．大量にかつ安定して発生するた め，従来セメント材料等に再利用されてきた．また，水 砕スラグ自体は安定した材料であり，産業廃棄物に係る 判定基準を超える有害物質が検出されないなど，土木材 料としての有用性が高いが, 遊離 $\mathrm{CaO}$ を含むため, 水 中に存在する場合に $\mathrm{pH}$ が高くなる.

高橋（1997）は，港湾工事においてもその利用は進ん でおり苅田港，青森港および神戸港において大量に使用 された実績があること，また，ある程度海水交換が行わ れる海域であれば，環境に与える影響はあまり問題とな らないが，注意して対応すべき問題であることを指摘し ている．埋立材としての事例を見ると，水面上での利用， または水面下に没する場合でも水密性の高い構造での利 用が多いようである。一方，最近では水砕スラグを用い た浅場は，底性生物や魚類の生息場，藻場としても利用 可能なことが報告されている（例えば，宮田ら，2000； 鶴谷, 2003).

関西空港 2 期工事では，護岸背面の裏込め材として水 砕スラグの利用が計画されたが，完成後の圧密沈下によ り水砕スラグが水面下に没し，また緩傾斜護岸構造のた め水密性が低いことから, 護岸完成後の水砕スラグの環 境に対する影響を慎重に調査することとした。

\section{2. 検 討 方 法}

裏込材として用いる水砕スラグからの高 $\mathrm{pH}$ の溶出水 は地盤内を移動し, その間に海水や地盤の緩衝効果を受

\footnotetext{
* 正会貝 博(工) 東洋建設(株) 鳴尾研究所

** 正会員 修(工) 東洋建設(株) 鳴尾研究所

$* * * \quad$ 関西国際空港(株) (現在国土交通省)

$* * * * \quad$ 関西国際空港用地造成
}

け， $\mathrm{pH}$ が低下する．また，適当な相似則もないことか ら, 本研究では現地における再現性を高めるため, 水路 内に現地地盤材料で大縮尺の模型を作成し，海水を用い て潮汐変動を与えた場合の $\mathrm{pH}$ の時空間変化を測定する ことで，水砕スラグの影響を評価することとした。また， こうした物理・化学過程を全て取り込んだ適切な数値モ デルを構築することは容易でないが，既に開発された飽 和・不飽和浸透流の解析コードにアルカリ度の化学平衡 計算を組み合わせる手法で水路実験の再現を試み, $\mathrm{pH}$ 変化に対する機構を考察した。

\section{3. 水路実験}

\section{（1）実験方法}

a）実験水路および検討断面

実験は，東洋建設（株）の大型不規則波水路（長さ55 $\mathrm{m} \times$ 高さ $2 \mathrm{~m} \times$ 幅 $1 \mathrm{~m})$ を用いて行った．模型は縮尺 を1/5として，造波板部および消波斜面部に海水が入ら ないように仕切った内部に配置した (図-1 参照).

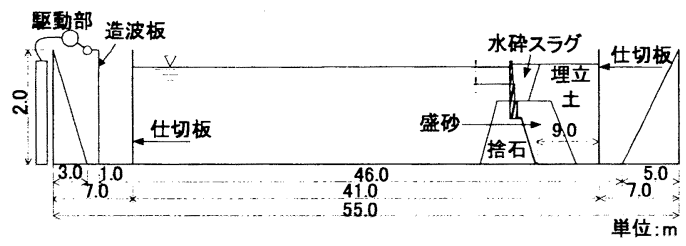

図-1 水路内の模型配置

検討断面は，埋立後10年経過時および20年経過時の沈 下量を考慮した 2 ケースを想定した（図-2 参照）。実験 では沈下に伴う地盤高を変化させることは困難であるた め, 地盤高の差は水深を変化させることで対処した。

b ）型の作成方法

地盤内の物質移動が $\mathrm{pH}$ の分布に関与することから, 現地地盤と同等の透水性を有し，かつ均一となるように 模型地盤を作成した。搬入された現地地盤材料の透水係 


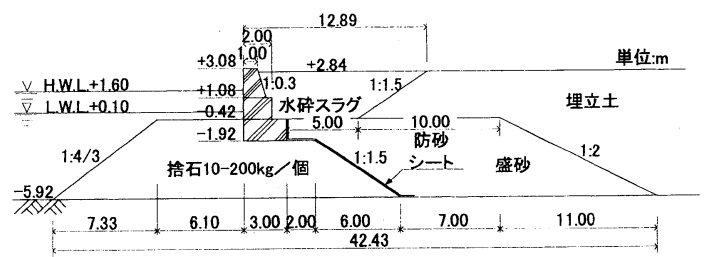

(a) 10 年経過時

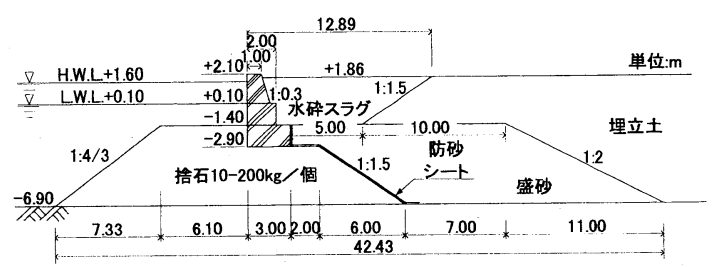

(b) 20 年経過時

図-2 検討断面（現地スケール）

表-1 現地地盤材料の透水係数

\begin{tabular}{c|c|c}
\hline 種 類 & 透水係数 $(\mathrm{cm} / \mathrm{s})$ & 備 \\
\hline 考 \\
\hline 盛砂 $($ ま土) & $2.67 \times 10^{-2}$ & 最大粒径約 $100 \mathrm{~mm}$ \\
\hline 埋立土 (頁岩) & $2.51 \times 10^{-1}$ & 最大粒径約 $300 \mathrm{~mm}$ \\
\hline 水砕スラグ & $5.14 \times 10^{-1}$ & \\
\hline
\end{tabular}

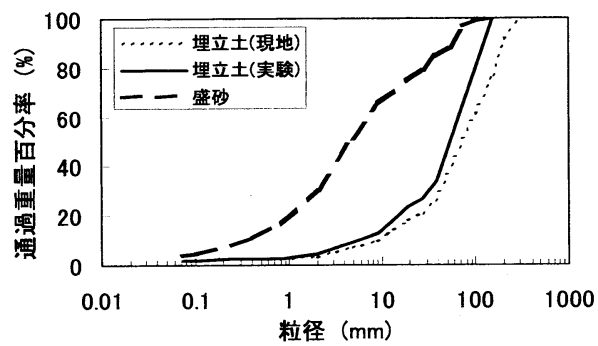

図-3 粒度分布

数および粒度分布をそれぞれ表-1 および図-3 に示す。

盛砂の場合，最大粒径が約 $100 \mathrm{~mm}$ であったので，現 地材料をそのまま利用した。また現地における飽和湿潤 密度はほほ $2.0 \mathrm{~g} / \mathrm{cm}^{3}$ であったことから，調合時には乾 燥密度で $1.6 \mathrm{~g} / \mathrm{cm}^{3}$ となるように $20 \mathrm{~cm} /$ 層で密度管理を 行った．埋立土の場合，最大粒径が約 $300 \mathrm{~mm}$ であった ため，水路幅および層厚を勘案して最大粒径が $150 \mathrm{~mm}$ として分級材料を調合した．また，間隙が大きく透水性 が高い条件および水締めによる沈下が発生しないように, 乾燥密度 $1.8 \mathrm{~g} / \mathrm{cm}^{3}$ を目標に $30 \mathrm{~cm} /$ 層で密度管理を行っ た. 水砕スラグは，他材料に比べて粒度がそろっており， 搬入材料をそのまま用いても均一性は確保できると考え た。なお，捨石の場合，粒度が比較的そろっていたこと および透水係数が他の材料に比べて約 2 オーダ大きいた め, 密度管理は行わなかった。 また，防砂シートは現地 材料をそのまま敷設するとともに，パラペットはアクリ ル製とし，目地からの流出がないように密閉構造とした.

\section{c）実験範囲の設定}

護岸背面側の実験範囲は，一潮汐間における透水層内 の水粒子の水平方向移動距離が, 潮位変動による物質移 動の影響範囲になると考えて設定した。その場合，関空 一期島においては外海の潮位変動に同期して空港島内域 の水位が変動しているとの報告を考慮し, 透水性をある 程度大きく想定することとした. 埋立土の透水係数を $k$ $=10^{1} \mathrm{~cm} / \mathrm{s}$ とすれば, 一潮汐間における透水層内の水 粒子の水平方向移動距離は約 $45 \mathrm{~m}$ （模型值で約 $9 \mathrm{~m}$ ) と なることから，捨石ののり尻が仕切板から $9 \mathrm{~m}$ となる ように設置すれば，仕切板の影響を低減できると考えた。

d）潮位変動の発生方法および測定

水路から約 $100 \mathrm{~m}$ 離れた岸壁から海水を水中ポンプに て汲み上げ，正弦振動の潮汐（フルード則により1周期 333分）として作用させた（図-4 参照). また, 埋立土 および護岸前面の水路底に，それぞれ間隙水圧計および 水圧計を設置し，水位変動をモニタリングした。

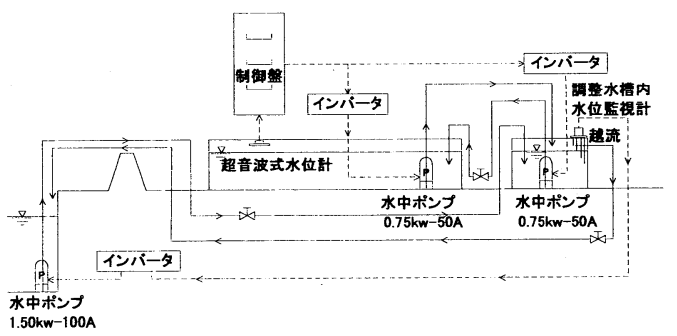

図-4 潮汐発生装置の概要

e ） $\mathrm{pH}$ の測定方法

$\mathrm{pH}$ は44点で測定し, 地盤内にはその中の26点を配置 した (図-5 参照)。なお, 水砕スラグの影響がないと考 えられるバックグラウンド（BG）の測定点は, 護岸模 型より $40 \mathrm{~m}$ 離れた仕切り板の前面とした.

測点箇所には予め塩ビ管 $(\phi 13)$ を設置し, これにビ ニールチューブを接続し，真空ポンプによって全測点同 時に海水を採水ビンに採取した (写真-1 参照). 採取し

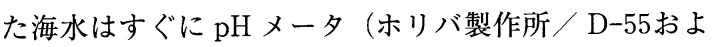
び F-55）で測定を実施した，塩ビ管の採水口部は L 字 形に加工し，地盤からの細粒分を混入しないようにステ ンレスメッシュ（60メッシュ／インチ）にて防護した。 実験時の採水は図-6に示す時間で行った．採水時間間

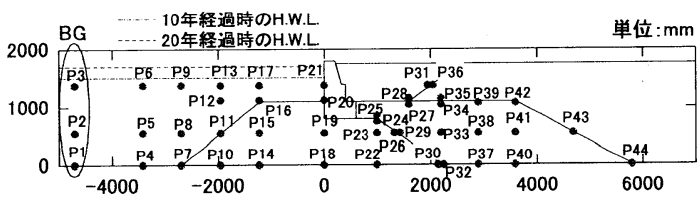

図-5 pH の測定点（模型スケール） 
隔は，測定開始時には密に，その後は時間間隔を徐々に 大きくしたが，最大間隔は半周期とした.
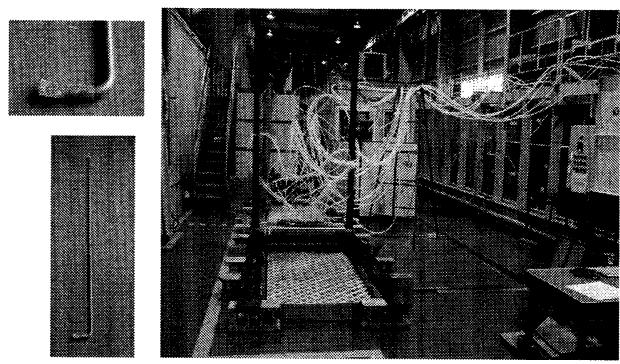

写真-1 採水装置

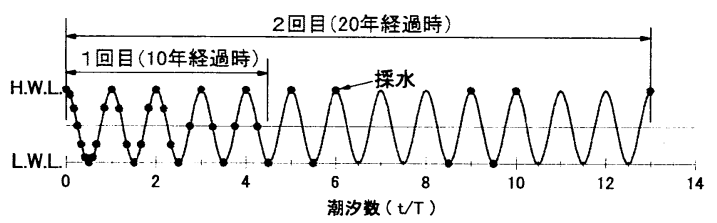

図-6 採水の夕イミング

\section{（2）実験結果および考察}

a）地盤内の水位変動

測定結果は図示できないが, H.W.L. 時から水位が低 下する際に, 地盤内の排水遅れのために位相に若干のず れが生じたものの, 地盤内の水位変動と潮位変動はほぼ 同じであった.

b ） $\mathrm{BG}$ における $\mathrm{pH}$ の変動

10 年経過時および20年経過時における BGにおける $\mathrm{pH}$ の変動を図-7に示す. 図中には, 潮位および BG の 平均值を併せて示した. $\mathrm{BG}$ の $\mathrm{pH}$ は原海水の特性を表

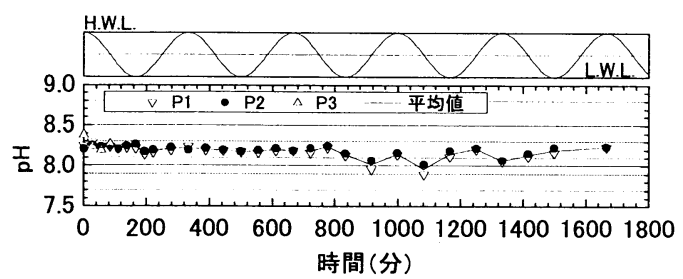

(a) 10 年経過時

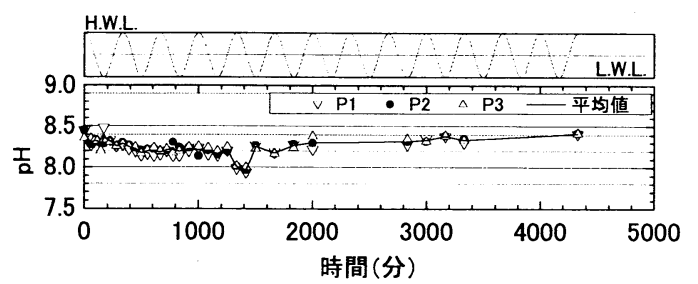

(b)20 年経過時

図-7 BGにおける $\mathrm{pH}$ の変動
すもので，10年経過時における全時間の平均值は 8.19 , 平均値の最小および最大はそれぞれ7.96および8.28であ った。また 20 年経過時における全時間の平均値は 8.25 , 平均值の最小および最大はそれぞれ7.97および 8.42 とな ったことから，ほぼ同等の条件で実験が行われたと言え る. 大阪湾における海水の $\mathrm{pH}$ は流れ，成層化および河 川水の流入の影響を受けるが，1987年－2001年に測定さ れた表層水の平均值は8.18であり，実験時の $\mathrm{pH}$ はこれ に近かった（海上保安庁海洋情報部の HP よりデータ入 手). $\mathrm{BG}$ における $\mathrm{pH}$ は平均值から 0.2 程度の範囲で変 動することから, 各測点の $\mathrm{pH}$ は各時刻の $\mathrm{BG}$ の平均值 との比較において評価することが妥当と考えられた。

c ）護岸付近における $\mathrm{pH}$ の変動

水砕スラグの没水量が大きい 20 年経過時について護岸 付近の $\mathrm{pH}$ の時間変化を示す. 図-8 はパラペット背後 の測点 $\mathrm{P} 26-\mathrm{P} 29$ の $\mathrm{pH}$ を $\mathrm{BG}$ の平均值とともに示した ものである. 水砕スラグおよび盛砂の境界で水砕スラグ 内の $\mathrm{P} 28$ における $\mathrm{pH}$ ( $\left.\triangle \mathrm{E}^{-}\right)$の平均值は 9.70 となり全 測点中最大となった。一方, 同じ境界で盛砂内の $\mathrm{P} 27$ の $\mathrm{pH}$ (○印) は潮位変動に応じて増滅を繰り返すように なるが，平均值は9.04となっており，僅かの移動の間に $\mathrm{pH}$ は約 0.7 低下したことがわかる.

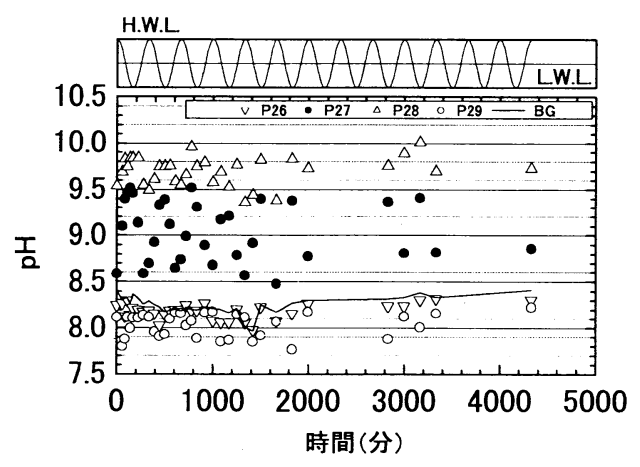

図-8 測点 P 26- P 29における pH の変動（20年経過時）

その下部に当たる盛砂内の $\mathrm{P} 29$ の $\mathrm{pH}$ (○印) は潮汐 変動に応じた変化を示すとともに，平均值は 8.03 となり BG のそれ (8.25) よりも小さくなっている. pH の低 下は, 別途実施したカラム試験の結果から, 盛砂が持つ アルカリ緩衝効果によると考えられる，一方，捨石内の $\mathrm{P} 26$ の $\mathrm{pH}$ ( $\nabla$ 印) の平均值は 8.19 と上昇し, 変化の様 子もほほ BGと同じになった。これは，捨石層内では透 水性が高く, 海水の中和・緩衝や希釈効果（(財) 沿岸 開発技術研究センター・鐵鋼スラグ協会，1989）による ものと考えられる.

次に，捨石内およびパラペット前面の海中部における $\mathrm{P} 14-\mathrm{P} 25$ の $\mathrm{pH}$ の変化を図-9 に示す. 盛砂との境界近 
傍で $\mathrm{BG}$ より $\mathrm{pH}$ が低くなるけれども，捨石内部ではほ ほ BG と同じである.

また， 10 年経過時および 20 年経過時ともに, $\mathrm{pH}$ の継 続的な上昇や低下は見られなかった。

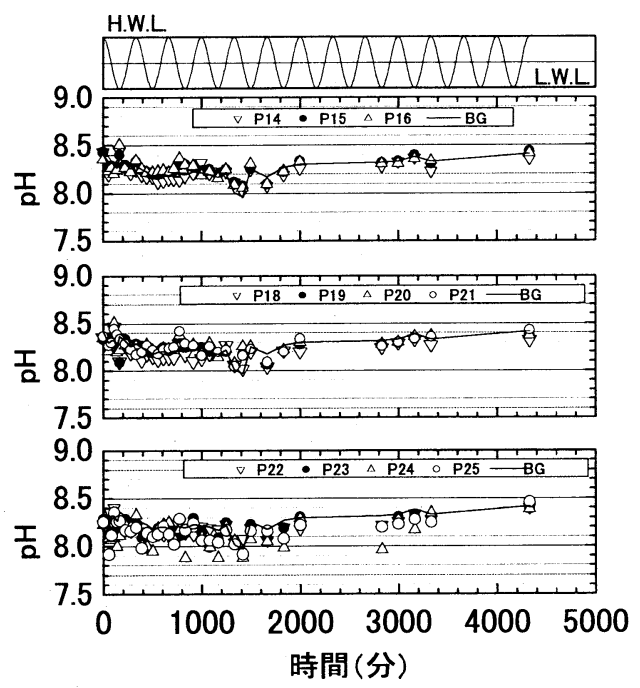

図-9 測点 P 14- P 25における pH の変動（20年経過時）

\section{d ) $\Delta \mathrm{pH}$ の分布}

図-10 は各測点の $\mathrm{pH}$ と $\mathrm{BG}$ の平均值からの偏差 $\Delta$ $\mathrm{pH}$ のコンタを示す. L.W.L. 時および H.W.L. 時におけ る $\Delta \mathrm{pH}$ の分布に大きな差異は見られず，両ケースとも に捨石内から護岸前面の海中部では $\Delta \mathrm{pH}$ はほほ 0 であ る. 一方, 水砕スラグ内では溶出水の影響によって $\mathrm{pH}$ は正となり，また盛砂内では緩衝効果によって負と なる様子が明らかである．盛砂中央部に近いほど $\mathrm{pH}$ の 低下が大きいことから, 緩衝効果は移動長さと密接に関 連していることが示唆される，以上より，現地での再現 性や数値モデルの構築において，地盤の緩衝効果を取り 入れる必要性が見出される。なお緩衝効果は時間的に低 滅することがカラム試験によって確認されており，その 取り扱いには十分な注意が必要である。ただし，今回の 条件では緩衝効果によって $\mathrm{pH}$ の低下する領域は地盤内 に限られており，海水と接するような領域への影響は小 さかった。

\section{4. 移流拡散解析}

\section{（1）方 法}

解析手法の詳細は, 馬場ら（2005）を参照されたい. ここでは，以下に簡単に説明する．解析は，移流拡散解 析による物質の地盤内移動と化学平衡に基づくアルカリ 度の計算を組み合わせて行った，地盤内の流速は，西垣 ら（1995）による解析コード「Dtransu-2D・EL」を用

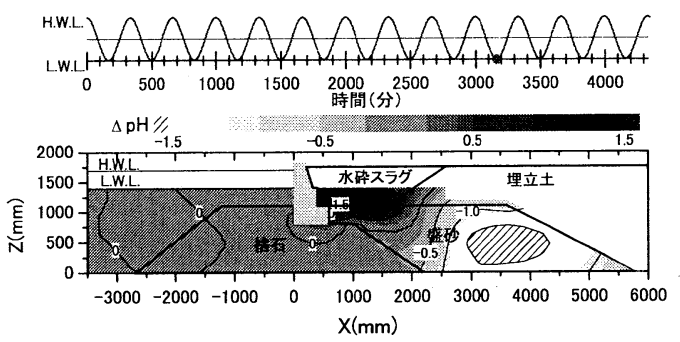

(a)L.W.L.時

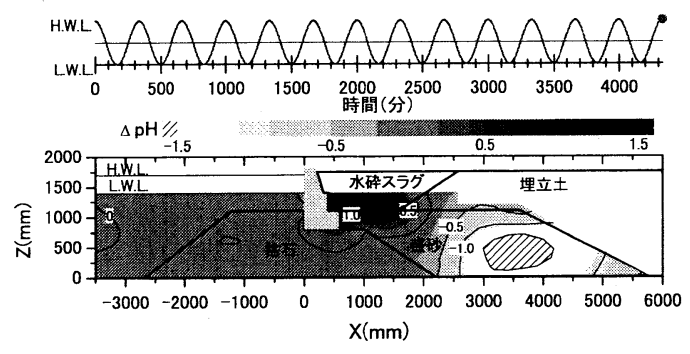

(b)H.W.L.時

図-10 $\Delta \mathrm{pH}$ の空間分布（20年経過時）

い，飽和・不飽和浸透流解析による実流速を算出した. アルカリ度の計算では，拡散揖よび移流に対してそれぞ れ中心差分および CIP 法（中川ら，2004）を適用する ことで精度よく求める工夫を行った，海水のアルカリ緩 衝効果として, 海水中の炭酸水素イオンが炭酸イオンに 変化する効果と海水中の $\mathrm{Mg}^{2+}$ イオンが $\mathrm{pH} 9.3$ 前後から 水酸化マグネシウム $\mathrm{Mg}(\mathrm{OH})_{2}$ となり沈降することを考 慮した。また，前述のように盛砂の緩衝効果を取り入れ る必要性が示唆されることから, カラム試験の結果を定 量化して盛砂と水砕スラグの境界部で与えることとした。 なお, $\mathrm{pH}$ は次式で定義されるアルカリ度 $A L K$ $(\mathrm{mol} / \mathrm{l})$ から算出した.

$$
\mathrm{ALK}=\left[\mathrm{HCO}_{3}^{-}\right]+2\left[\mathrm{CO}_{3}^{2-}\right]+\left[\mathrm{HO}^{-}\right]-\left[\mathrm{H}^{+}\right]
$$

ここに，[ ]はモル濃度 $(\mathrm{mol} / \mathrm{l})$ を表す.

解析モデルは 10 年経過時の模型断面を対象とし, 図 -11に示すように設定した，上部工法線部の境界条件は, 浸透流解析では潮位変動に対応する全水頭を与えた。 ま た, 移流拡散解析では濃度境界を設定し, 海水が流入す る場合は原海水の濃度を与えた。

\section{(2) 解析結果}

水砕スラグと盛砂の境界および盛砂と捨石の境界にお ける解析結果および実験結果を比較した結果を図-12 お よび図-13に示す.

実験では海水を水路内に貯留する過程で水砕スラグか らアルカリ分が溶出するが，解析ではそれを考慮できな 


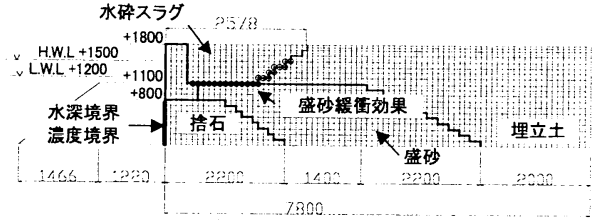

図-11 解析モデル（水路実験）

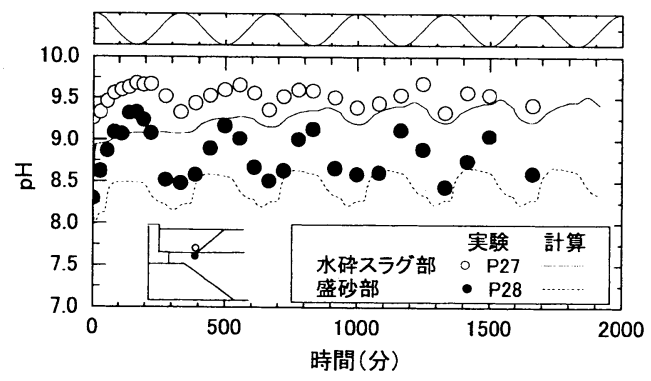

図-12 水砕スラグおよび盛砂の境界付近での比較

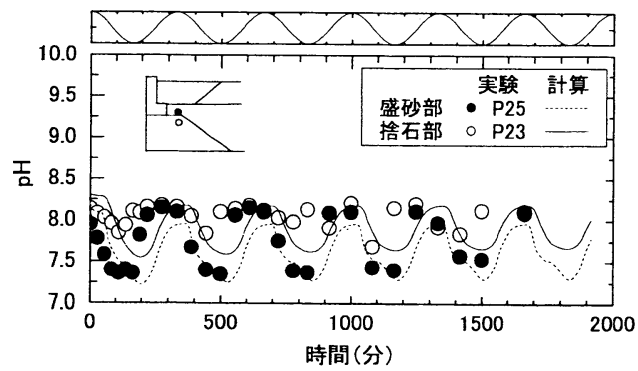

図-13 盛砂および捨石の境界付近での比較

いことから初期条件が完全には一致しないものの，捨石 近傍で両者の值は良い一致を見せている。一方、スラグ 周辺ではスラグ内の $\mathrm{pH}$ は良く一致しているが，盛砂境 界では解析結果の方が低い值を示す。これは，盛砂の緩 衝効果を境界部でのみ与えていることが原因と考えられ る. ただし，実験における捨石と水砕スラグ間の盛砂厚 が $30 \mathrm{~cm}$ であり，カラム実験時のカラム長 $(40 \mathrm{~cm})$ に 近いことで捨石境界では同等の緩衝効果となり，捨石近 傍では $\mathrm{pH}$ が一致したと考えられる。

また, L.W.L. 時に水砕スラグに近い場所では溶出水 の影響で $\mathrm{pH}$ が高くなり，盛砂を通り捨石に近づくと緩 衝効果によって逆に $\mathrm{pH}$ が低下する現象や H.W.L. 時に
海水の影響でいずれの測点も $\mathrm{BG}$ と同程度の $\mathrm{pH}$ になる 現象を計算はよく表しており，数值モデルの妥当性が伺 える.

\section{5. をと め}

本研究によって得られた主要な結果をまとめて示す.

1）現地地盤材料で大縮尺の模型を作成し，海水を用い て潮汐変動を与えた場合の $\mathrm{pH}$ の時空間変化を測定 . 評価した。 その結果, 水砕スラグから高 $\mathrm{pH}$ の溶出水 は潮汐変動に伴い地盤中を移流拡散するが, 海中およ び捨石中では，海水の中和・緩衝および希釈効果が卓 越し，水砕スラグの影響は認められなかった。

2 ）盛砂および埋立土内の $\mathrm{pH}$ は地盤の緩衝効果によっ て BG 值よりも小さくなる.

3 ）海水の化学平衡および土の緩衝効果を考慮した移流 拡散モデルによって，実験時の $\mathrm{pH}$ の時間・空間変化 をよく表すことを確認した。

謝辞：(財) 災害科学研究所・椹木 亨所長揖よび大阪 大学大学院・出口一郎教授には, 実験手法から結果の評 価に渡りご指導，ご助言をいただいた。また，実験では 東洋建設（株）の赤崎 正氏，上田悦子氏および知振佐 苗氏の協力を得た。ここに記して深甚なる謝意を表する。

\section{参 考 文 献}

(財) 沿岸開発技術研究センター・鐵鋼スラグ協会 (1989)：港湾工 事用スラグ利用手引き書, $36 \mathrm{p}$.

鶴谷広一(2003)：底質環境の違いによるアマモの発芽・生育に関 する実験的研究について, 第29回底質浄化技術セミナー, テ キスト, pp. 30-42.

中川 啓・和田信一郎 - 籾井和朗 (2004)：CIP 法と化学平衡計算 による飽和土壤中の多成分溶質反応輸送解析, 土木学会論文 集, No.761/ II -67, pp. 81-89.

西垣誠・菱谷智幸・橋本 学・河野伊一郎 (1995)：飽和・不飽和 領域における物質移動を伴う密度依存地下水流の数值解析手 法に関する研究, 土木学会論文集, No.511/ III - 30, pp. 135-144.

馬場慎太郎・藤原隆一 - 三宅達夫 · 守谷壮之 · 中谷行男 (2005)： 水砕スラグ溶出水に対する海水の化学平衡を考虑した移流拡 散解析, 第40回地盤工学研究発表会, pp. 1273-1274.

宮田康人 ·沼田哲始 - 豊田惠聖・佐藤義夫 ·小田静 · 岡本 隆 (2000): 高炉水砕スラグの底質改善効果, 海洋開発論文集, 第16巻, pp. 345-350. 